\title{
Psychological Traumas in Children and Adolescents: Causes and Nature of Maladaptation Signs
}

\section{Reshetnikov MM${ }^{1}$, Bobrov $\mathrm{AE}^{\mathbf{2}}$ and Ulasen $\mathrm{TV}^{3 *}$}

${ }^{1}$ East-European Institute of Psychoanalysis, St. Petersburg, Russia

${ }^{2}$ Moscow Scientific and Research Institute of Psychiatry - Subsidiary of FSBU

"National medical research Center of Psychiatry and Narcology named by V.P. Serbskogo" of the Ministry of Healthcare of Russia, Moscow, Russia

${ }^{3}$ Federal State Budgetary Educational Institution of Higher Education "Smolensk State Medical University" of the Ministry of Healthcare of Russia, Smolensk, Russia

*Corresponding Author: Ulasen TV, Candidate of Medical Sciences, Associate Professor of the Department of Psychiatry, Narcology and Psychotherapy of the Doctors' Skills Upgrading Faculty of the Federal State Budgetary Educational Institution of Higher Education "Smolensk State Medical University", Smolensk, Russia.

DOI: 10.31080/ASPE.2020.03.0222
Received: January 17, 2020;

Published: February 11, 2020

(C) All rights are reserved by Ulasen TV., et al.

\section{Abstract}

The article contains the results of differentiated clinical psychopathological, psychodiagnostic and laboratory (estimation techniques for unspecific adaptational blood reactions using lymphocyte levels parameters (Garkavi., et al.) research of adaptational abilities of boarders of social protection institutions (SPI). The obtained results reveal the polymorphism of clinical, social and psychological signs of maladaptation in this population that can be explained by peculiarities of premorbid traumatic experience (mostly violation), duration and impact degree of traumatic factor, condition of functional systems, individual characteristics of the child. Some factors appear to be particularly significant. These are conditions of the child's development, presence/absence of psychological support factor, presence/absence of social environment that "teaches" an aggressive and hostile behavior. The authors have come to the conclusion that the integrated approach to assessing adaptational abilities in this population is highly important and it can be used by pediatricians, family doctors and psychiatrists when developing individual psychocorrective strategies to be implemented at a social protection institution.

Keywords: Orphans; Deprivation; Kinds of Child Abuse; Mental Disorders; Deviant Behavior

\section{Abbreviation}

SPI: Social Protection Institution.

\section{Introduction}

The study of consequences of child's traumas has recently become interdisciplinary. The battered child syndrome was firstly identified as an individual group of child abuse consequences in 1962 by American pediatrician C. Henry Kempe, who spoke mostly about physical cruelty [28]. Some years later the definition was expanded to include physical cruelty, sexual abuse, emotional cruelty, kinds of neglect (deprivation of food, clothes, education and medical care denial) [1].

Modern foreign studies describe mechanisms of affective disorders, suicidal behavior, posttraumatic stressful disorder, and addictive behavior from the perspective of forming "an insecure attachment behavior" $[6,16-18,24-27,29]$. This is supported by the findings of modern genetic studies, that proved a harmful impact of the wrong environment on genes work (the so-called "epigenetic process") at an early age, which leads to an asocial behavior [9]. However, in spite of a long-term experience of studies devoted to a psychological trauma, and a high activity of specialists who are interested in the issues of child and adolescent abuse, there are still unsolved problems of complex assessment of adaptational abilities in children and adolescents from a deprived background [15]. With this respect, boarders of social protection institutions (SPI) make up a specific cohort, due to their heavy traumatic psychological experience, which makes it difficult to develop appropriate complex rehabilitation programs. The study results show high rates of psychological development deviations as well as considerable prevailing of physical and mental disorders in this population, which affects the condition of the body adaptational system in general $[1-3,7,10,11]$. Thus, it is a complex clinical, social and psychologi- 
cal approach that will allow to describe the type of maladaptation signs in patients at their first admission to a social protection institution. Moreover, it will contribute to the optimization of preventive and curative interventions in this population with respect to the orphanage factor and place of living before a child's admission to a SPI.

The purpose of the study is to evaluate the variety of adaptational (social and psychological, physiological) reactions of the body within the whole structure of adaptational resources in children and adolescents with different family status at their first admission to a social protection institution.

\section{Method and Materials}

The study was conducted on the base of the Federal State Budgetary Educational Institution of Higher Education "Smolensk State Medical University" of the Ministry of Healthcare of Russia.

Two groups of children and adolescents were examined. The primary group consisted of 181 children (female - 79, male - 102) at the age of $\geq 3$ to $\leq 17$ years from SPIs (orphans, social orphans and children from needy families). The primary group was made up by two subgroups: 1st subgroup of orphans (true and social ones), $2^{\text {nd }}$ subgroup of children and adolescents from a deprived background, who were brought up at social protection institutions. The average age (M(SD)) of the children and adolescents being examined was 11.5 (3.6) years. The control group included children and adolescents $(\mathrm{n}=237)$, who studied in a secondary school with the average age (M(SD)) of 13.05 (3.3) years.

The family status of the patients examined in the primary group was characterized by the following structure: true orphans $(n=13$; $7.2 \%)$, social orphans ( $\mathrm{n}=42 ; 25.4 \%)$; children from a deprived background, who were brought up in families ( $n=126 ; 67.4 \%)$.

\section{Ethical issue}

The study was conducted according to the protocol as agreed with an independent Ethics Committee of the Federal State Budgetary Educational Institution of Higher Education "Smolensk State Medical University" of the Ministry of Healthcare of Russia. The study was conducted after obtaining the consent of the head of the institution who is a legal representative of the children and adolescents participating in the study.

The examination of the SPI boarders was performed using clinical psychopathological and psychodiagnostic methods. The following tools were applied: semi-structured interview to identify signs of a post-traumatic stress in children; coping strategy technique for school children; Deviant Behavior Questionnaire in minors; Buss - Durkee Hostility Inventory; "Adolescents about parents" Questionnaire aimed at revealing mindset, behavior and parenting practices as they are seen by adolescents. Since the majority of the examined adolescents had no fathers, the questionnaire was used to determine the mother's style of upbringing $[4,13,14,22]$. To estimate unspecific adaptational blood reactions by the lymphocyte levels, laboratory methods of Lyubov Kh. Garkavi., et al. were used [8]. The percentage of lymphocytes in white cell count is called an adaptational reaction alarm. According to Garkavi's theory, there are following unspecific adaptational reactions: training; calm activation; elevated activation; reactivation reaction; stress reaction. Reactivation reaction as well as stress reaction is an unspecific adaptational reaction of the body to a strong impact that creates unspecific grounds for many diseases.

Age-specific study of mental disorders was conducted based on the mental development periods identified by D.B. Elkonin [23]. Thus, the following groups were identified in the study: the $1^{\text {st }}$ age group ( $\geq 3$ to $\leq 6$ years old); the $2^{\text {nd }}$ age group ( $\geq 7$ to $\leq 10$ years old); the $3^{\text {rd }}$ age group ( $\geq 11$ to $\leq 14$ years old); the $4^{\text {th }}$ age group ( $\geq 15$ to $\leq 17$ years old). Statistical analysis was performed using F-test, Mann-Whitney test and Spearman rank correlation, cross tables (cross tabulation method). Correlation relationships were assessed using Cheddock scale [12].

\section{Results and Discussion}

The data obtained show a high rate of non-psychotic mental disorders in boarders of social protection institutions which accounts for $89 \%$. In children examined $(n=181)$ organic emotionally labile disorder, mixed conduct and emotions disorder, as well as specific disorders of learning skills were most common. However, there was no statistical significance in distributing mental disorders by gender (female - 79, male - 102). The study of frequency of mental disorders was conducted in boarders of social protection institutions using the mental development periods identified by D.B. Elkonin. Persistently high frequency of organic emotionally labile disorder (from 66.7 to 33.3\%) in different age groups was striking. A gradual percentage increase of mixed conduct and emotions disorder from juniors to seniors (from 13.3 to 33.3-26.1) was observed. Some mental disorders were peculiar only for juniors. These were a phobic anxiety disorder of childhood (13.3\%) and a reactive attachment disorder (6.7\%).

The study of frequency of mental disorders related to the presence/absence of family education (family or orphanage) in pooled cohort of the examined boarders of social protection institutions seems to be of a high practical relevance. In general, mental disorders when studied by Mann-Whitney test were more common in orphans (social and true) compared to children brought up in families. In particular, the most common events observed in orphans were depression ( $p=0,000039 \leq 0,05)$, an organic emotionally labile (asthenic) disorder ( $p=0,013771 \leq 0,05)$, a somatoform autonomic dysfunction ( $p=0,001679 \leq 0,05)$, as well as a mild cognitive disorder ( $p=0,043748 \leq 0,05)$. While the most common events in children brought up in families were mixed specific developmental 
disorders and a marked tendency to a phobic anxiety disorder of childhood ( $p=0,075422 \leq 0,05)$.

Taking into account a considerable traumatic experience, the nature of the experienced traumatic events was also studied in boarders of social protection institution $(n=181)$. The findings demonstrated that the most common events were financial straits ( $\mathrm{n}=164 ; 90.6 \%)$, parents' chemical addictions $(\mathrm{n}=100 ; 55,2 \%)$; neglect $(n=93 ; 51.4 \%)$, death of a parent(parents) $(n=29 ; 16.0 \%)$, physical abuse ( $\mathrm{n}=24 ; 13.3 \%$ ), sexual abuse $(\mathrm{n}=4 ; 2.2 \%)$. Besides, a statistically significant contingency between the majority of psycho-traumatic factors affecting SPI boarders and their different psychopathologic conditions was determined. Thus, physical abuse was contingent on a depressive episode $(p=0,034 \leq 0,05)$, death of parents caused depression $(p=0,0009 \leq 0,05)$ and somatoform autonomic dysfunction ( $p=0,0060 \leq 0,05)$, parents' alcohol and drug addiction led to depression $(p=0,0087 \leq 0,05)$, somatoform autonomic dysfunction $(p=0,0141 \leq 0,05)$ and hyperkinetic disorders $(p=0,0201 \leq 0,05)$, sexual abuse was linked to a mixed conduct and emotions disorder $(p=0,0213 \leq 0,05)$. In this context, the analysis of physiological adaptational reactions using the methods of Lyubov Kh. Garkavi., et al. proves to be highly significant [8]. The results of the frequency rate of unspecific blood adaptational reactions in SPI boarders are shown in table 1. Lymphocytic parameters in clinical blood analysis were used as signs of a particular adaptational reaction.

\begin{tabular}{|l|c|c|}
\hline Unspecific adaptational reactions & Absolute number & $\mathbf{\%}$ \\
\hline Stress reaction & 21 & 21,44 \\
\hline Training & 28 & 28,57 \\
\hline Calm activation & 14 & 14,28 \\
\hline Elevated activation & 24 & 24,49 \\
\hline Reactivation reaction & 11 & 11,22 \\
\hline
\end{tabular}

Table 1: Frequency rate of unspecific adaptational reactions in SPI boarders $(\mathrm{n}=98)$.
The data obtained show the prevailing tendency of unspecific adaptational reactions in a pooled group of SPI boarders, which reflects a tension of physiological adaptational systems, such as stress reactions, training, elevated activation.

The comparative study of frequency of unspecific adaptational reactions was performed in boarders of social protection institutions (SPI) and pupils of secondary schools. The results are shown in table 2.

The presence of blood stress reactions not accompanied by any marked psychopathological symptoms at a clinical psychopathological examination is likely to be the sign of a latent general maladaptation syndrome with underlying permanent psycho-trauma, including latent forms of psychosomatic disorders, which requires a further psychopathologic and pathopsychological study. In particular, the data obtained demonstrate that orphan adolescents are more likely to suffer a somatoform autonomic dysfunction of upper gastrointestinal disorders. The study revealed different types of adaptational profiles in SPI boarders with considerable traumatic experience in regard to the type of unspecific adaptational reactions of the body. This fact and other results of clinical psychopathologic and psychodiagnostic studies determine the necessity of individual approach to developing psychocorrective strategies by subgroups (orphans or children and adolescents from families).

Comparative analysis of clinical and social and psychological criteria of traumatic experiences in SPI boarders revealed different profiles of a stress reaction in subgroups of adolescents with different social status by DSM-IV criteria, which allow to determine clinical symptoms of posttraumatic stress disorder [20]. In general, in subgroups under the comparison high scores by A criterion of "immediate response"" to a stressful situation are most common. However, such scores are statistically higher in orphan adolescents compared to adolescents living in birth families $(\rho=$ $0,0144<\alpha=0,05)$, and there have been no intracluster correla-

\begin{tabular}{|l|c|c|c|c|c|}
\hline \multirow{2}{*}{$\begin{array}{c}\text { Unspecific adaptational } \\
\text { reactions }\end{array}$} & \multicolumn{2}{|c|}{$\begin{array}{c}\text { Pupils of secondary } \\
\text { schools (n = 237) }\end{array}$} & \multicolumn{2}{c|}{$\begin{array}{c}\text { Boarders of social protec- } \\
\text { tion institution (n = 98) }\end{array}$} & \multirow{2}{*}{$\begin{array}{c}\text { Difference significance } \\
\text { p } \leq \mathbf{0 , 0 5} \text { by F-test }\end{array}$} \\
\cline { 2 - 5 } & Absolute number & $\mathbf{\%}$ & Absolute number & $\mathbf{\%}$ & \\
\hline Stress reaction & 8 & 3,37 & 21 & 21,44 & 0,0000 \\
\hline Training & 23 & 9,72 & 28 & 28,57 & 0,0004 \\
\hline Calm activation & 80 & 33,76 & 14 & 14,28 & 0,0028 \\
\hline Elevated activation & 97 & 40,92 & 24 & 24,49 & 0,0279 \\
\hline Reactivation reaction & 29 & 12,23 & 11 & 11,22 & 0,4896 \\
\hline
\end{tabular}

Table 2: Differences in frequency of unspecific adaptational reactions in pupils of secondary schools $(\mathrm{n}=237)$ and boarders of social protection institutions (SPI) $(n=98)$ using F-test.

tions noticed with other criteria of traumatic experiences. This finding is likely to indicate the fact that traumatic experiences were totally squeezed out by orphans and social orphans which implies a further psychological examination and individual approach to a choice of psychocorrective measures. Intracluster correlations between criteria of traumatic experiences do not include $\mathrm{F}$ criterion which demonstrates a functioning disorder. It is likely to be related 
to a greater focus on traumatic situations, including SPI admission, in this population, as well as to the involvement of these experiences into complaints structure, and the lost of supporting factor with a subsequent creating of another style of a social behavior compared to orphans. These differences in adolescents' evaluation of traumatic experiences can point out to a different nature of experienced traumatic events in the context of deprivation, and to a different evaluation of these events by orphan adolescents and adolescents living with families, which, if considered with other factors, can ultimately determine the differences in chosen behavior coping strategies.

Thus, the results of the initial test performed to identify the most common behavior coping strategies in stressful situations demonstrate the lack of statistically significant differences in adolescents of both subgroups from social protection institutions. However, the repeated test to examine the most effective coping strategies in stress coping revealed a group distinction in the examined population [25-27]. The following effective strategies are statistically significant in adolescents of the 1st subgroup (orphans): prevailing coping strategies of "avoidance" ("I'm sleeping" strategy $p=0,0182<a=0,05$ and "I'm trying to relax and keep calm" $p=0,0293<a=0,05$ ), which, if left untreated, in future can lead to an addictive behavior, suicide-related conditions and psychosomatic disorders. On the contrary, adolescents from families are characterized by prevailing affectively aggressive coping strategies with a further potential risk of maladaptation of aggressive and delinquent types. To perform a differentiated analysis of the signs of behavior maladaptation, the study of deviant behavior forms in SPI boarders was conducted with regard to the orphanage factor [19]. The obtained results demonstrate a statistically significant prevalence of mild addictive $(p=0,00<0,05)$, aggressive $(p=0,01<0,05)$, delinquent $(p=0,00<0,05)$ forms of deviant behavior and a statistically significant prevalence of a lowered level of a social behavior $(p=0,00<0,05)$ in orphan adolescents (true and social). However, the study of frequency of mercenary, aggressive and socially passive types of deviant behavior in subgroups of SPI adolescents did not identify credible differences based on the analysis of individual cards of the boarders. It should be mentioned about differences found in "masks" of squeezed out traumatic experiences that unconsciously can determine the behavior of the examined patients. Orphan adolescents demonstrate prevailing tendencies to suspicion, negativism, while adolescents living in birth families often show a high aggression index, feeling of resentment and guilt (without statistical difference being achieved), and "irritation" which is more common. The identified peculiarities comply with the SPI adolescents' evaluations of traumatic experiences, and are related to social focus disorders. This fact can explain a different nature of forecasted further social scenarios.
One should note that the assault experienced in childhood assumes a high probability of violence to someone or self-violence in adult life. In these circumstances, the question arises: why does a person, who witnessed and experienced assault, being an adult person start to express aggression and hostility to people surrounding him/her? On the one hand, the psychic traumas in the circumstances of a deprivation experience are likely to have caused the psychological readiness in examined adolescents to response aggressively to the hardships due to the projecting and transferring of negative reactions on the surrounding people, this fact ultimately permitted them to justify their aggression. On the other hand, in this case it is necessary to mention the notion of a "life scenario" that is not only the best strategy for the child to survive in a "hostile world", but it was also brought to life in accordance with the child's emotions and his/her way of the reality testing [6]. Perry and Bussey (1984) pointed out that a huge gap between children and parents, absence of tenderness and love, indifference or liberal attitude towards the signs of the child's aggression, methods of force (in particular, physical punishment) as disciplinary measures instead of care and calm explanation, affect the development of aggression features in children. Thus, according to the data obtained in our research, the damaged "reality testing" can be seen from the determined contiguity factor for the identified psychopathological deviations of pathocharacterological nature and experienced traumatic events; "hostile type" of mother's upbringing (by U-criterion: $\rho=0,04<\alpha=0,05$ ) identified by the questionnaire "Adolescents about parents" in orphan adolescents [19].

\section{Conclusion}

The data obtained demonstrate polymorphism of clinical and social and psychological signs of maladaptation in boarders of social protection institution that can be explained by peculiarities of premorbid traumatic experience (mostly violation), duration and impact degree of trauma factor, condition of functional systems, individual characteristics of the child. Some factors appear to be particularly significant. These are conditions of the child's development, presence/absence of psychological support factor, presence/absence of social environment that "teaches" an aggressive and hostile behavior.

Thus, it is the integrated approach with regard to the results of clinical psychopathological and psycho diagnostic studies, analysis of unspecific adaptational reactions of the body that will help to extend and specify the structure of maladaptation in boarders of social protection institutions which can be used by pediatricians, family doctors and psychiatrists when developing individual psychocorrective strategies to be implemented at social protection institution 


\section{Conflict of Interest}

The authors declare no conflict of interest.

\section{Bibliography}

1. Asanova NK. "Rukovodstvo po preduprezhdeniju nasilija nad det'mi" [Guidelines for the Prevention of Abuse of Children]. Moscow: VLADOS (1997): 504.

2. Avakjan TV and Volikova SV. "Jemocional'nye narushenija u detej-sirot, prozhivajushhih $\mathrm{v}$ detskih domah raznogo tipa" [Emotional disorders in orphans living in various types of orphanages. Proceedings of the All-Russian Scientific and Practical]. Materialy Vserossijskoj nauchno-prakticheskoj konferencii s mezhdunarodnym uchastiem «Mezhdisciplinarnyj podhod v ponimanii i lechenii psihicheskih rasstrojstv: mif ili real'nost'?» (Sankt-Peterburg, 14-17 maja 2014 g) [Conference with international participation "Interdisciplinary approach to understanding and treating mental disorders: myth or reality?" (St. Petersburg, May 14-17, 2014). Saint Petersburg: Izd-vo Al'ta Astra (2014): 215-217.

3. Alekseenkova EG. "Personality in terms of mental deprivation". Saint Petersburg: Piter (2009): 96.

4. Batarshev AV. "Temperament and character: Psychological diagnosis". M: VLADOS-PRESS (2001): 336.

5. Bobrov $\mathrm{AE}$ and Ulasen TV. "Rezul'taty sravnitel'nogo analiza struktury psihicheskih rasstrojstv u vospitannikov uchrezhdenij social'noj zashhity i uchashhihsja obshheobrazovatel'nyh shkol". Siberian Bulletin of Psychiatry and Addiction 104. 3 (2019): 33-40.

6. Boulbi Dzh. Privjazannost' [Attachment]. Moscow: Gardariki (2003): 477.

7. Vostroknutov NV and Perezhogin LO. "Formation of personality disorders in juvenile offenders, homeless and neglected". Questions of the Mental Health of Children and Adolescents 1 (2008): 25-41.

8. Garkavi L.X., Kvakina E.B., Kuz`menko T.S. Pediatrics 5 (1996): 107-109.

9. Genri Dzh., et al. "Unfavorable environment at an early age and subsequent development: the role of epigenetics". Questions of Psychology 1 (2016): 154-162.

10. Zlova TP., et al. "Influence of family education on the formation of addictive behavior of adolescents". Far Eastern Medical Journal 4 (2011): 49-51.

11. Kalacheva IO., et al. "Psychogenic disorders in children and adolescents (issues of diagnosis and rehabilitation)". Psychiatry and Psychopharmacotherapy 1 (2003): 23-25.
12. Kobzar' AI. "Applied mathematical statistics". For engineers and scientists. Moscow (2006): 816

13. Leus EhV., et al. "Diagnostics of deviant behavior of minors". Bulletin of Chelyabinsk State Pedagogical University 9 (2012): 268278.

14. Nikol'skaja IM and Granovskaja PM. Psychological protection in children". Saint Petersburg: Rech', (2000): 507.

15. Nuckova EV. "The structure of the psychological consequences of sexual violence and abuse against children and adolescents". Psychology and Law 6.3 (2016): 104-121.

16. Patnem F. "Diagnosis and treatment of multiple personality disorders". Moscow: Kogito-Centr (2004): 440.

17. Prihozhan A and Tolstyh N. "Mental development of orphanage pupils". Moscow (1990): 175-204

18. Proselkova ME. "Deprivation disorders in orphans". Proceedings of the IV Congress of Pediatricians of Russia "The health of children and adolescents" (Moscow, November 17-18, 1998)]. Moscow (1998): 91-92.

19. Reshetnikov MM and Ulasen' TV. "Psychological analysis of aggressive tendencies in adolescents who first entered a socio-protective institution". Clinical and Special Psychology 7.2 (2018): 111-123.

20. Reshetnikov MM and Ulasen TV. "The study of socio-psychological and clinical manifestations of traumatic experiences in pupils of social protection institutions". International Research Journal 7.61 (2017): 96-99.

21. Smirnova EO., et al. "Features of the mental development of children raised outside the family". Orphans of Russia: problems, hopes, future. Moscow (1994): 57-58.

22. Tarabrina NV. "Psychology of post-traumatic stress". Moscow (2009): 304.

23. Jel'konin DB. "To the problem of periodization of mental development in childhood". Questions of psychology 4 (1971): 6-20.

24. Blizard Ruth A. "Disorganized attachment, development of dissociated self Astates, and a relational approach to treatment". Journal of Trauma and Dissociation 4.3 (2003): 27-50.

25. Ainsworth MDS and Bowlby J. "An ethological approach to personality development". American Psychologist 46 (1991): 331341.

26. Amstadter A and Vernon L. "Emotional reactions during and after trauma: A comparison of trauma types". Journal of Aggression, Maltreatment and Trauma 16.4 (2008): 391-408. 
27. Cuevas C., et al. "Psychological distress as a risk factor for re-victimization in children". Childs Abuse and Neglect 34.4 (2010): 235-243.

28. Kempe RS and Kempe CH. “Child Abuse”. Fontana. Open books. London (1978): 157.

29. Meyerson LA., et al. "The influence of childhood sexual abuse, physical abuse, family environment, and gender on the psychological adjustment of adolescents". Child Abuse and Neglect 26 (2002): 387-405.

\section{Assets from publication with us}

- Prompt Acknowledgement after receiving the article

- Thorough Double blinded peer review

- Rapid Publication

- Issue of Publication Certificate

- High visibility of your Published work

Website: www.actascientific.com/

Submit Article: www.actascientific.com/submission.php

Email us: editor@actascientific.com

Contact us: +919182824667 